\title{
Low genetic variation in a Pacific cycad: conservation concerns for Cycas seemannii (Cycadaceae)
}

\author{
Gunnar Keppel
}

\begin{abstract}
The conservation status of Cycas seemannii, native to Vanuatu, New Caledonia, Fiji and Tonga, is assessed based on isozyme analysis, abundance estimates and factors affecting the survival of the species. Genetic variation in the species is low and genetic differentiation between populations is high, as compared to plants in general and to other cycads. Lower genetic variation was detected in a fragmented population as compared to less disturbed populations. Low gene flow was also detected, implying little contact between the various populations. A conservative estimate of 17,000 individuals remaining in the wild was obtained, with more than half of these located on the islands of Vanuatu. Accounts of past abundance suggest declining population sizes, most likely the result of repeated burning. Other factors that may be contributing to the decline are
\end{abstract}

decreasing importance to and protection by humans, habitat alteration for agricultural and developmental purposes, and poor dispersal and recolonisation potential. An assessment based on the present estimated abundance and what is known of recent declines in numbers, indicates that the species should be categorised as Vulnerable on the IUCN Red List. On some of the densely populated islands, such as Viti Levu in Fiji and Nukualofa in Tonga, the species is locally Endangered or Critically Endangered. Possible conservation measures are suggested, and it is emphasised that populations on different islands must be considered separately because of their genetic differentiation.

Keywords Cycads, Cycas seemannii, genetic variation, islands, South Pacific.

\section{Introduction}

The biota of oceanic islands are usually more susceptible to change and extinction relative to those of continental areas (Fosberg, 1963; MacArthur \& Wilson, 1967; Ono, 1998). Anthropogenic threats, including over-hunting, over-collecting, habitat destruction and deterioration, introduction of non-native organisms, and hybridization with numerically larger cogeners may also have relatively greater impacts on islands (Riesenberg \& Svensen, 1996). The conservation status of the plant family Cycadaceae (cycads) on islands has received attention because of the decline of several species as a result of over-collection and habitat destruction (Jones, 1993; Osborne, 1995). Excessive trade in cycads has led to all species being listed in Appendix I or II of the Convention on the International Trade in Endangered Species (CITES, 1999). While this has significantly reduced trade in cycads, the destruction of their habitat continues (Whitelock, 1995).

The genus Cycas is considered to be the oldest genus of cycads, with fossils dating back c. 200 million years

\footnotetext{
Gunnar Keppel Department of Biology, School of Pure and Applied Sciences, The University of the South Pacific, P.O. Box 1168, Suva, Fiji Islands. E-mail keppel_g@usp.ac.fj

Received 9 August 2000. Revision requested 15 November 2000. Accepted 7 September 2001.
}

(Norstog \& Nicholls, 1997). Most species are found in South-east Asia and Australia, but species occur in Japan to the north, Madagascar and East Africa to the west, and Melanesia and Tonga to the east. Although none of the 94 species of Cycas are included in the 2000 IUCN Red List (Hilton-Taylor, 2000), Hill and Stevenson (1998) consider 27 to be threatened to some degree and 19 to be Data Deficient (sensu IUCN, 1994).

Cycas seemannii is an arborescent cycad that reaches $5-12 \mathrm{~m}$ in height, with a growth rate of $5-15 \mathrm{~cm}$ per year. It occurs on numerous islands of Vanuatu, New Caledonia, Fiji and Tonga (Fig. 1). Its primary habitat is forests, limestone terraces, beaches and cliffs, but it is now also found in grasslands as relics of previous vegetation (Keppel, 1999, 2001).

All cycads are dioecious, and pollen has to be transported from male to female plants. Although wind and/or animal pollination may occur in some species (Niklas \& Norstog, 1984; Ornduff, 1991), no insect pollinator has yet been observed on C. seemannii, and pollination is presumed to be solely by wind (Keppel, 1999, 2001). Long distance seed dispersal is mainly by oceanic currents, unlike other cycads, the seeds of which sink in water (Hill, 1994). No terrestrial or avian dispersal agent has been observed. Developing seedlings are mostly found clustered around the mother tree, suggesting that gravity is the main terrestrial dispersal agent (Keppel, 1999, 2001). 


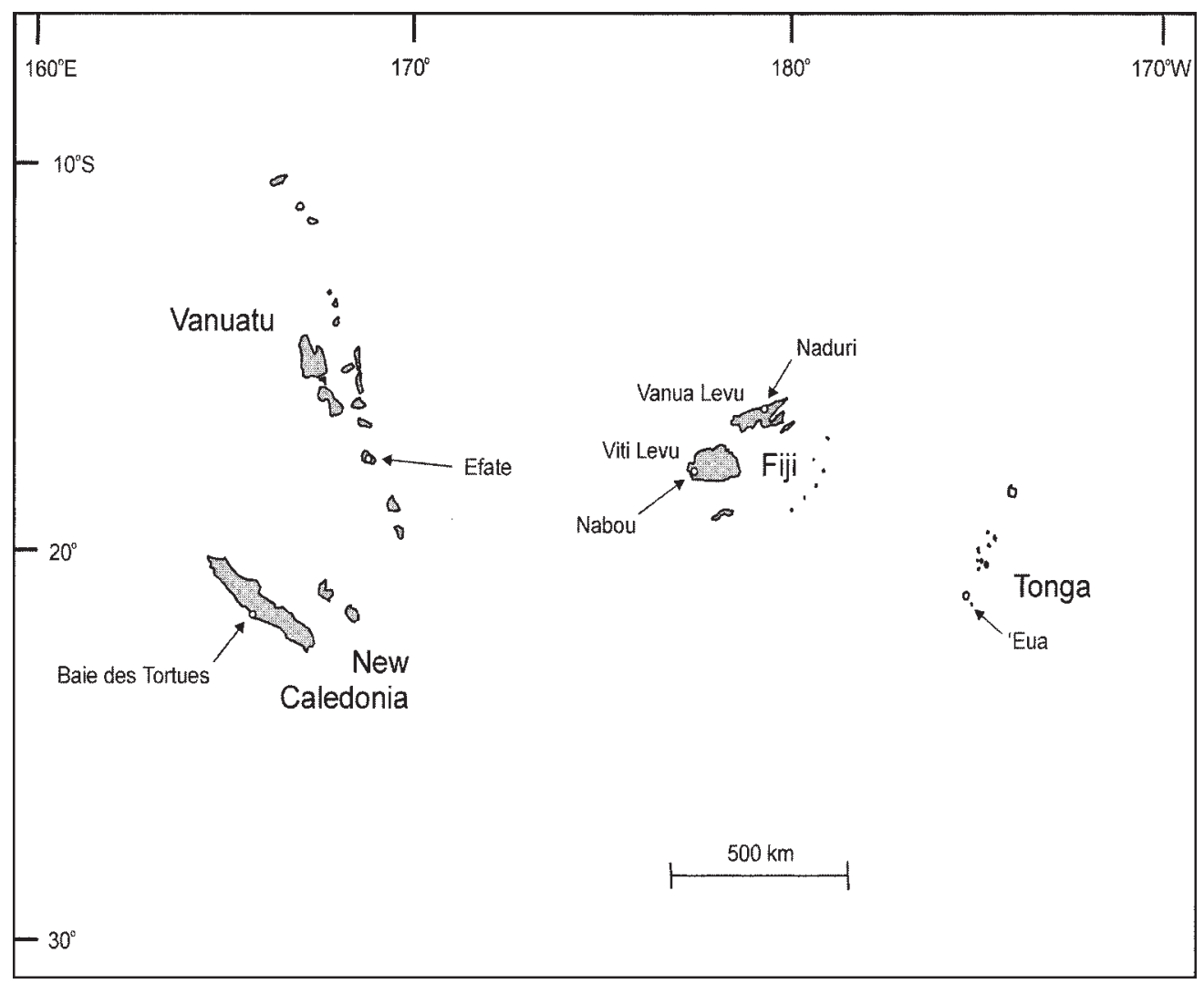

Fig. 1 Location of study sites.

C. seemannii was categorised as Rare on the 1997 IUCN Red List of Threatened Plants (Walter \& Gillet, 1998), and assessed as Vulnerable by Osborne (1995) and Doyle (1998). Osborne (1995) based his classification on an estimate of 5,000 individuals remaining in the wild. Osborne (1995) suggested that the present conservation status of all cycads is based on insufficient information and should be revised using knowledge of population demography, genetics and assessment of actual and potential risk factors. In this paper I assess the status of $C$. seemannii in the insular South-west Pacific by studying its genetic structure, reviewing data on its abundance and assessing apparent risk factors to its survival, and I suggest measures for its conservation.

\section{Methods}

Five populations of Cycas seemannii were studied in detail: one each in New Caledonia, Vanuatu and Tonga, and two in Fiji (Fig. 1). General natural history observations were made on an additional seven wild populations in Fiji and, to a lesser extent, on cultivated specimens at the University of the South Pacific and at the Sacred Heart Cathedral, both in Suva, Fiji.
At the Baie des Tortues, a few kilometres south-east of Bourail in New Caledonia, individuals of $C$. seemannii emerge from a thicket of Leucaena leucocephala (a problematic weed on the island; T. Jaffré, pers. comm.) on a limestone terrace. Signs of human disturbance are evident in the form of pedestrian tracks through the thicket. Leaf samples were collected randomly in this population of c. 200 individuals.

On the island of Efate in Vanuatu (near a place known as Devil's Point), C. seemannii grows as part of the understory (only a few individuals being emergent) on slopes covered by dense lowland rainforest (classified as 'medium-stature forest heavily covered with liana'; Mueller-Dombois \& Fosberg, 1998). Several remnant plants grow in a coconut plantation on the adjacent coastal plain. Leaf samples were collected from individuals that were a minimum of $c .20 \mathrm{~m}$ apart in this population of at least 1,000 individuals.

At the southernmost tip of the island of 'Eua in Tonga, C. seemannii forms a prominent component of the understory of the coastal forest (cliff vegetation and HernandiaTerminalia coastal forest; Drake et al., 1996) on a limestone terrace with little or no soil cover above vertical cliffs of $100 \mathrm{~m}$ height. A vehicle track runs through the forest, part of which has been converted into a cattle ranch. 
Leaf samples were collected from plants 10-15 m apart in this population of at least 1000 individuals.

A natural population grows amongst a planted stand of commercial pine Pinus caribaea at the Nabou Pine Station on the leeward, drier, western side of Viti Levu, the largest island of Fiji. It is at an altitude of c. $210 \mathrm{~m}$, $5-10 \mathrm{~km}$ from the coast on hilly terrain with talasiga vegetation, a term referring to Fiji's pyrophytic grasslands and the associated poor, degraded soils (Latham, 1979, 1983), and consists of several fragmented clusters of 20-70 individual cycads. Leaf samples were taken from individuals $15-20 \mathrm{~m}$ apart within two fragments, one consisting of 60 and the other of 20 individuals.

Samples from a second population in Fiji, growing in a forest near Naduri on Vanua Levu, the second largest island of Fiji, and consisting of several hundred individuals, were obtained from individuals that were transplanted in 1994 by D. Watling to the Sigatoka Valley on Viti Levu. The transplantation was carried out to save some of the seedlings; the natural population is burnt annually, and seedlings often do not survive fires. The transplanted individuals were grown from suckers and seedlings that were randomly collected from the Naduri population (D. Watling, pers. com.)

Estimates of the number of individuals present in each country were obtained from my own observations, published literature and by personal communications. Accurate estimates are difficult to obtain because C. seemannii is found on numerous small islands (Fiji, for example, consists of more than 500 islands). In addition, the species can also occur up to several $\mathrm{km}$ inland in remote and often inaccessible areas. Abundance in Fiji was estimated using counts made during my extensive travels throughout the Fiji Islands (Viti Levu, Vanua
Levu, Kadavu, Taveuni, Qamea and the Lomaiviti Group) and by other naturalists (D. Watling, M. V. Tuiwawa, S. Vodonaivalu, M. Fisher and S. Masitoqi). On Vanuatu I estimated the total population in the archipelago by counting individuals in one sixth of the total area, and extrapolating to the entire population and the entire archipelago. Similarly for Tonga and New Caledonia the estimates are conservative extrapolations of the numbers found in the populations studied.

Leaf sections were collected from 30 different adult individuals in each of the five study populations and analysed using starch gel electrophoresis (SGE). Procedures followed Conkle et al. (1982) with some modifications (Keppel, 1999; Keppel et al., in press). Twenty presumptive loci of thirteen enzyme systems were resolved and scored and were used in the statistical analysis (Table 1).

Several estimates of genetic variation (the extent of the diversity of alleles in the genome) were calculated for each population and for the species as a whole using BIOSYS1 (Swofford \& Selander, 1989). These estimates were the mean number of alleles per locus $(A)$, percentage of loci polymorphic ( $P$, at the 99\% level), observed mean heterozygosity $\left(H_{\mathrm{o}}\right)$ and the heterozygosity expected $\left(H_{\mathrm{e}}\right)$ in Hardy-Weinberg equilibrium (Nei, 1978). Populations having higher values of these statistics are considered genetically more variable than those with lower values. BIOSYS1 was also used to calculate Wright's $F_{\mathrm{ST}}$ statistic. This ranges between 0 and 1 and estimates the genetic differentiation between populations. $G_{\text {ST }}$ (Nei, 1973), an alternative estimate of inter-population differentiation, was calculated to facilitate comparison with other works (Hamrick \& Godt, 1992). GDA software (Lewis \& Zaykin, 1999) was used to

Table 1 Enzyme systems resolved in this study. Nomenclature and abbreviations follow Murphy et al. (1996), based on IUBNC. E.C. No. = Enzyme Commission number.

\begin{tabular}{|c|c|c|c|}
\hline Enzyme & Locus Abbreviation & E.C. No. & Buffer* \\
\hline Asparate aminotransferase & AAT-1, -2 & 2.6.1.1 & $\mathrm{B}$ \\
\hline Fluorescent esterase & fEST-1 & 3.1.1.- & A \\
\hline Formaldehyde dehydrogenase & FDH-1 & 1.2.1.1 & A \\
\hline Fructose-biphosphate aldolase & FBA-1 & 4.1.2.13 & $\mathrm{D}$ \\
\hline Glucose-6-phosphate dehydrogenase & G6PDH-1 & 1.1.1.49 & $\mathrm{B}$ \\
\hline Glutamate dehydrogenase & GTDH-1 & 1.4.1.2 & B \\
\hline Isocitrate dehydrogenase & IDH-1 & 1.1.1.42 & $\mathrm{D}$ \\
\hline Malate dehydrogenase & $\mathrm{MDH}-1,-2,-3,-4$ & 1.1.1.37 & $\mathrm{D}$ \\
\hline Phosphogluconate dehydrogenase & PGDH-1, -2 & 1.1.1.44 & $\mathrm{D}$ \\
\hline Phosphoglucomutase & PGM-1 & 5.4 .2 .2 & $\mathrm{D}$ \\
\hline Shikimate dehydrogenase & SKDH-1 & 1.1.1.25 & $\mathrm{D}$ \\
\hline Triose-phosphate isomerase & TPI-1, -2 & 5.3.1.1 & $\mathrm{A}$ \\
\hline UTP-glucose-1-phosphate uridylytransferase & UGUT-1, -2 & 2.7.7.9 & B \\
\hline
\end{tabular}

* = A, B, D refer to buffers A (tris citrate/lithium borate), B (citrate/sodium borate) and a pH 8 version of buffer D (morpholine citrate) of Conkle et al. (1982). 
calculate the co-ancestry coefficient $(\theta$, Reynolds et al., 1983; Weir \& Cockerham, 1984), an estimate of interpopulation differentiation that is considered to have less bias and a smaller variance than $F_{\mathrm{ST}}$ (Slatkin, 1985; Cockerham \& Weir, 1993). The co-ancestry coefficient was then used to calculate an estimator of the gene flow between the populations, $\mathrm{Nm}$, using the formula $N \mathrm{~m}=1 / 4(1 / \theta-1)$ (after Wright, 1951). Nm, therefore, ranges from 0 (absence of gene flow) to infinity, and is considered low (insufficient to prevent populations from diverging genetically) if it is less than 0.25.

Statistics for the loci studied were calculated using POPGENE, version 1.21 (Yeh et al., 1997). For each polymorphic locus the observed heterozygosity $\left(H_{\mathrm{o}}\right)$, the heterozygosity expected $\left(H_{\mathrm{e}}\right)$ in Hardy-Weinberg equilibrium (Nei, 1978) and the genotypic fixation indices $\left(F_{\mathrm{IT}}\right.$ and $\left.F_{\mathrm{IS}}\right)$ were determined. Positive values of $F_{\mathrm{IT}}$ (which measures the decrease of heterozygosity between sub-populations relative to the heterozygosity of the whole population) and $F_{\text {IS }}$ (which measures the decrease of heterozygosity between different individuals relative to the heterozygosity of the subpopulation) imply a deficiency of heterozygotes compared to those expected under random mating, while negative values imply an excess.

\section{Results}

Cycas seemannii is moderately common throughout the Fiji Group; c. 4,000 individuals were counted (Table 2) and the actual number is expected to be higher. C. seemannii is still abundant on Vanuatu, and I estimated the total population in the archipelago to be at least 10,000 individuals (Table 3). This approximation was derived by counting 200 individuals in part of the study population and extrapolating to $c .1,000$ individuals for the whole population. This figure was used to estimate numbers in the large populations on the less disturbed, northern side of the island and on the remaining islands of the archipelago (Schmid, 1975; P. Ala \& S. Chanel, pers. comm.). On 'Eua, Tonga, I counted $>1,000$ individuals in the study population and estimated the total number to be at least 2,000, because the cycad is also abundant on the slopes of the eastern side of the island (Drake et al., 1996) and occurs on other islands of the Tonga group (Franklin et al., 1999; K. D. Hill, pers. comm.). In the study population on New Caledonia $>200$ individuals were counted, resulting in an estimate of at least 1,000 individuals based on a total of 10 recorded populations (Laubenfels, 1972). A conservative estimate for the total population size of C. seemannii is, therefore, c. 17,000 (Table 3).

For most loci heterozygosity was lower than that expected under Hardy-Weinberg equilibrium (Table 4). This lack of heterozygotes was also indicated by highly positive $F_{\text {IS }}$ and $F_{\text {IT }}$ values for fEST-1, MDH-2, PGDH-1 and PGM-1. Genetic variation was low in all populations (Table 5), and especially so at Nabou.

Genetic variation in $C$. seemannii at the species level $\left(P_{\mathrm{s}}=50.0, A_{\mathrm{s}}=1.8, H_{\mathrm{es}}=0.138\right)$ was similar to that of plant species in general $\left(P_{\mathrm{s}}=51.3, A_{\mathrm{s}}=1.97, H_{\mathrm{es}}=0.150\right.$;

Table 2 Minimum estimates of the number of Cycas seemannii plants in Fiji based on my observations (GK) and personal communications.

\begin{tabular}{lccl}
\hline Island Group & $\begin{array}{c}\text { Number of } \\
\text { Populations }\end{array}$ & $\begin{array}{c}\text { Estimated No. } \\
\text { of Individuals }\end{array}$ & Sources \\
\hline Viti Levu & 9 & 1,050 & R.H. Phillips, S. Vodonaivalu, GK, Taqaqe and Malomalo villagers \\
Vanua Levu & 15 & 1,432 & M.V. Tuiwawa, R.H. Phillips, S. Vodonaivalu, D. Watling, GK \\
Yasawa Group & 1 & 500 & M. Fisher \\
Kadavu Group & 4 & 350 & S. Vodonaivalu, GK \\
Taveuni and nearby islands & 5 & 250 & M.V. Tuiwawa, D. Watling, GK \\
Lomaiviti Group & 5 & 370 & D. Watling, GK \\
Lau Group & 5 & 160 & D. Fuller, L. Mataitini, M.V. Tuiwawa \\
TOTAL & 44 & 4,112 & \\
\hline
\end{tabular}

Table 3 Minimum estimates of the number of Cycas seemannii on different Pacific countries, based on my observations (GK), personal communications and literature (see text).

\begin{tabular}{lrl}
\hline Country & Estimated Number & Sources \\
\hline Fiji & 4,000 & See Table 2 \\
New Caledonia & 1,000 & Extrapolation from study population (GK) to those mentioned by Laubenfels (1972) \\
Tonga & 2,000 & Drake et al. (1996), Franklin et al. (1999), GK \\
Vanuatu & 10,000 & S. Chanel \& P. Ala (pers. comm.), GK \\
TOTAL & 17,000 & \\
\hline
\end{tabular}


Table 4 Heterozygosity statistics for all polymorphic loci. $N$ = sample size (number of individuals), $H_{\mathrm{O}}=$ heterozygosity observed, $H_{\mathrm{E}}=$ heterozygosity expected (Nei, 1973), $F_{\mathrm{IS}}$ and $F_{\mathrm{IT}}-$ genotypic fixation indices (after Nei, 1987).

\begin{tabular}{llllrr}
\hline Locus & $N$ & $H_{\mathrm{o}}$ & $H_{\mathrm{e}}$ & \multicolumn{1}{c}{$F_{\mathrm{IS}}$} & \multicolumn{1}{c}{$F_{\text {IT }}$} \\
\hline fEST-1 & 125 & 0.000 & 0.597 & 1.000 & 1.000 \\
IDH-1 & 142 & 0.331 & 0.405 & -0.232 & 0.190 \\
MDH-2 & 142 & 0.035 & 0.476 & 0.815 & 0.928 \\
MDH-4 & 145 & 0.097 & 0.140 & -0.025 & 0.311 \\
PGDH-1 & 146 & 0.062 & 0.331 & 0.499 & 0.810 \\
PGDH-2 & 146 & 0.082 & 0.079 & -0.117 & -0.043 \\
PGM-1 & 144 & 0.056 & 0.208 & 0.401 & 0.732 \\
SKDH-1 & 135 & 0.230 & 0.421 & -0.123 & 0.471 \\
TPI-1 & 146 & 0.041 & 0.053 & 0.125 & 0.228 \\
TPI-2 & 146 & 0.020 & 0.020 & -0.053 & -0.010 \\
\hline
\end{tabular}

Hamrick et al., 1992). At the population level, however, genetic variation was much lower in $C$. seemannii $\left(P_{\mathrm{p}}=21.3, A_{\mathrm{p}}=1.2, H_{\mathrm{ep}}=0.057\right)$ than in plants in general $\left(P_{\mathrm{p}}=34.6, A_{\mathrm{p}}=1.52, H_{\mathrm{ep}}=0.113\right.$; Hamrick et al., 1992). Values for genetic variation were most similar to those of woody plants with endemic geographic ranges $\left(P_{\mathrm{s}}=42.5, A_{\mathrm{s}}=1.82, H_{\mathrm{es}}=0.078\right.$ and $P_{\mathrm{p}}=26.3, A_{\mathrm{p}}=1.48$, $H_{\text {ep }}=0.056$; Hamrick et al., 1992).

A high degree of inter-population differentiation $\left(F_{\mathrm{ST}}=0.594, \theta=0.695\right)$ was detected (Keppel, 1999). This means (using $F_{\mathrm{ST}}$ ) that only $40.6 \%$ of the observed genetic variation resides within populations and that the remainder is due to variation between populations. Gene flow estimates were very low $(\mathrm{Nm}=0.1097$, i.e. $<0.25$ ), implying that gene flow between the various populations is not enough to prevent them from diverging genetically. Differentiation between populations $\left(G_{\mathrm{ST}}=\right.$ 0.418), as measured by Nei's (1973) $G_{\mathrm{ST}}$, was higher than in plant species in general $\left(G_{\mathrm{ST}}=0.228\right.$; Hamrick et al.,
1992) and endemic woody plants $\left(G_{\mathrm{ST}}=0.141\right.$; Hamrick et al., 1992). This, together with the low gene flow estimate, indicates that the populations are genetically isolated to a large extent.

\section{Discussion}

This study gave an estimated population size for Cycas seemannii of c. 17,000 individuals, compared to the previous estimate of $c$. 5,000 mature individuals (Osborne, 1995). The actual population size is probably higher still because the species' geographical range includes hundreds of islands. However, numbers have dwindled dramatically over the last century and continue to do so. Direct evidence for this decline is scarce because there are no previous records of population numbers and sizes, but the decline is indicated indirectly by several factors. Shifting agricultural practices and developmental projects in coastal areas appear to be the major cause of decline. In Fiji, fire and poor or no regeneration endanger many of the remaining populations, and many, such as that in Nabou, are remnant populations surrounded by plantations of pine and sugarcane (Keppel, 1999). C. seemannii was a common component of the pyrophytic talasiga grasslands in Fiji early this century (Guppy, 1906; Mead, 1928), but this is no longer the case.

The perception of the plant in Fiji has changed from important and protected to almost unknown and unprotected. Seemann (1865-73) mentioned that several parts of C. seemannii, after proper detoxification, were included in the diet of the natives of Fiji, especially during times of food scarcity. The importance of the species has apparently been long forgotten and its use as a food plant is only remembered by a few elders, mostly from the more remote islands (L. Mataitini,

Table 5 Genetic variation parameters for each of the five Cycas seemannii populations studied, the mean population parameters, and the overall parameters for the species. Standard errors in parentheses. $N=$ mean sample size per locus, $A=$ number of alleles per locus, $A P=$ number of alleles per polymorphic loci, $P=$ percentage of loci polymorphic $(99 \%$ level $), H_{\mathrm{o}}=$ observed mean heterozygosity, $H_{\mathrm{e}}=$ heterozygosity expected.

\begin{tabular}{|c|c|c|c|c|c|c|}
\hline Population & $N$ & $A$ & $A P$ & $P$ & $H_{\mathrm{o}}$ & $H_{\mathrm{e}}$ \\
\hline 'Eua & $29.5(0.2)$ & $1.3(0.1)$ & $1.5(0.1)$ & 25.0 & $0.047(0.027)$ & $0.071(0.035)$ \\
\hline Nabou & $24.4(0.6)$ & $1.1(0.1)$ & $1.2(0.1)$ & 10.0 & $0.000(0.000)$ & $0.010(0.007)$ \\
\hline Naduri & $28.5(0.1)$ & $1.2(0.1)$ & $1.6(0.1)$ & 15.0 & $0.052(0.039)$ & $0.051(0.033)$ \\
\hline Baie des Tortues & $27.5(0.2)$ & $1.3(0.1)$ & $1.4(0.1)$ & 31.6 & $0.047(0.019)$ & $0.074(0.030)$ \\
\hline Efate & $30.0(0.0)$ & $1.3(0.1)$ & $1.6(0.1)$ & 25.0 & $0.088(0.046)$ & $0.079(0.039)$ \\
\hline $\begin{array}{l}\text { Population mean } \\
\text { (subscript } \mathrm{p} \text { in text) }\end{array}$ & $28.0(0.2)$ & $1.2(0.1)$ & $1.5(0.1)$ & 21.3 & $0.047(0.026)$ & $0.057(0.029)$ \\
\hline $\begin{array}{l}\text { Species overall } \\
\text { (subscript s in text) }\end{array}$ & $140.0(1.1)$ & $1.8(0.2)$ & $2.5(0.2)$ & 50.0 & $0.048(0.019)$ & $0.138(0.044)$ \\
\hline
\end{tabular}


pers. comm.). When I questioned them, most villagers in Fiji did not know of any uses for the plant and many younger people, especially on Viti Levu, did not know the native name of the plant. At present, the only common use of cycads is as ornamental plants. The situation is similar in other Pacific countries, with the exception of Vanuatu where the plant is still considered sacred (Thaman, 1992).

Cycads are not fire-resistant but are fire-tolerant (Norstog \& Fawcett, 1992; Wilson, 1993; Keppel, 2001). A fire that spread to the Nabou population from a sugar cane plantation a few kilometres away in December 1998 or January 1999 demonstrated the devasting effect fire can have on C. seemannii. One of the population fragments was reduced from about 400 individuals in March 1998 to some 50 plants by May 1999 (pers. obs.) and most of the remaining plants had charred stems. It therefore seems that the numerous populations of C. seemannii that were reported in the talasiga vegetation in the early 1900s were actually remnants of previous forest vegetation. Repeated burning seems to be the likely cause for their decline.

Poor seed dispersal and failure to recolonise former areas, even after several years (as observed on 'Eua, in Tonga, and in other areas), indicate that the plant may be especially vulnerable to local extinction.

The population in Nabou, Fiji, had the lowest genetic variation of all the populations studied (Table 5). This may be attributed to the fact that the population grows in a pine plantation and has been fragmented and disturbed by human activities. However, two other factors could have contributed to the low genetic variation observed. Firstly, only two of the remaining fragments were sampled; analysis of other fragments may reveal additional variation, although this does not explain the lack of heterozygosity (Tables 4 and 5). Secondly, the low genetic variation in this particular population could be partially caused by it having had low variation before fragmentation (Schoen \& Brown, 1991). The amount of genetic variation is believed to be positively correlated to fitness (Singh \& Zouros, 1978; Franklin, 1980; Frankel \& Soulé, 1981; Ledig et al., 1983; Lande, 1988; Millar \& Westfall, 1992; Lynch, 1996), and so the population at Nabou is likely to be more vulnerable to catastrophes and environmental change than the other populations.

Low genetic variation within populations and high differentiation between populations has also been noted in other cycads (Ellstrand et al., 1990; Walters \& Decker-Walters, 1991; Yang \& Meerow, 1996), except for Macrozamia riedlei (Byrne \& James, 1991). However, variation was even lower and differentiation was even higher in C. seemannii (Table 5) than in these other species (Keppel, 1999; Keppel et al., in press).
Vulnerability to fire, low dispersal and recolonisation potential, an apparent decline in genetic variation upon fragmentation in the Nabou population, and a decrease in numbers indicates that $C$. seemannii may be ecologically and genetically vulnerable to human impacts. The Red List status of the species would appear to be Vulnerable, based on criteria A1c; i.e. a suspected population reduction (A) of at least $20 \%$ (1) over the last three generations (c. 50 years for C. seemannii) based on a decline in area of occupancy (c).

However, on the more populated islands, the taxon could be locally categorised as Endangered or Critically Endangered. On Nukualofa in Tonga the species has become rare in the wild and is on the verge of local extinction (K. D. Hill, pers. comm.). On Viti Levu in Fiji only a few populations remain and, except for a population in the Mount Evans Range in the north-west (Lees, 1989), most of these are declining. A proposed nature reserve in this Range would include some of the cycad populations in the gullies at the feet of the range (Lees, 1989). The only population known to occur in an established protected area is that on the steep, eastern hills of 'Eua in Tonga (Drake et al., 1996).

Any conservation programme should ensure the longterm survival of a species and maintain its ecological and evolutionary processes, and both require the preservation of genetic variation (Hamrick \& Godt, 1996). At least 1,000 individuals are required to prevent the longterm effects of deleterious mutations and degradation of genetic variation, and more than 10,000 individuals are needed to maintain the adaptive genetic variation of a species (Lynch, 1996). Populations of C. seemannii on different island archipelagos are genetically distinct, and so any conservation programme will need to treat the different populations as separate entities in order to maintain the genetic variation and evolutionary processes in the taxon. Ideally at least two relatively undisturbed populations on each of the major islands within the range of the species should be identified for conservation purposes, with each of the two in different habitat types and at least one located at the coast to allow the maintenance of oceanic seed dispersal.

If possible, human-aided transport of seeds between the different islands should be prevented, because gene flow is naturally low. Artificial gene flow would alter the genetic structure and evolutionary processes of the cycad populations (Templeton, 1986), but because the species is used as an ornamental plant, control of this process will be difficult.

In populations such as that in Nabou, seeds could be collected and seedlings grown and then transplanted back to the original site. With subsequent protection this would help maintain an effective genetic population size. In addition, ex situ conservation strategies 
based on seed and germplasm collections in botanical gardens and other institutions would be of practical value for the conservation of the genetic variation of C. seemannii (Keppel, 1999; Keppel et al., in press). However, this can only assist and not replace in situ conservation

A decline in numbers, the low probability of recolonisation of formerly occupied areas, apparent loss of genetic variation in populations after fragmentation, and the fact that $C$. seemannii is approaching extinction on Viti Levu, Fiji, and Nukualofa, Tonga, underline the urgent need for implementation of conservation measures for this species. Such measures need to take into account that populations on different islands are genetically different and that as much as possible of the genetic variation present in the species should be preserved. The potential effects of agriculture, developmental projects, fires spreading from plantations, and rising sea levels will also need to be considered.

\section{Acknowledgements}

This work was funded by a grant from The University of the South Pacific. I wish to thank the French Embassy, Suva, which financially supported my M.Sc. studies and some of the field work through the French Ministry of Foreign Affairs. I am indebted to various people and organisations that significantly contributed to the success of this project: L'Institut Francaise de Recherche Scientifique pour le Development en Cooperation (IRD), Noumea, New Caledonia; The Department of Forestry of The Republic of Vanuatu, especially P. Ala and S. Chanel; The Institute of Forest Genetics, Placerville, California; The Department of Environment of The Republic of Fiji; Encephalartos; The Nabou Pine Station; P. D. Hodgskiss, S. W. Lee, M. F. Doyle, D. Watling, K. D. Hill, V. Tonga, M. V. Tuiwawa, T. Jaffré, S. Vodonaivalu, the late R. Phillips and P. F. Newell. I would also like to acknowledge the helpful reviews of S. A. Ghazanfar and M. Fisher.

\section{References}

Byrne, M. \& James, S.H. (1991) Genetic diversity in the cycad Macrozamia ridlei. Heredity, 67, 35-39.

CITES (1999) CITES. http:/ / www.wcmc.org.uk/CITES.

Cockerham, C.C. \& Weir, B.S. (1993) Estimation of gene flow from F-statistics. Evolution, 47, 855-863.

Conkle, M.T., Hodgskiss, P.D., Nunnally, L.B. \& Hunter, S.C. (1982) Starch Gel Electrophoresis of Conifer Seeds: A Laboratory Manual. Pacific Southwest Forest Range Experiment Station, Berkeley, USA.
Doyle, M.F. (1998) Gymnosperms of the SW Pacific - I. Fiji. Endemic and indigenous species: Changes in nomenclature, key, annotated checklist, and discussion. Havard Papers in Botany, 3, 101-106.

Drake, D.R., Whistler, W.A., Motley, T.J. \& Imada, C.T. (1996) Rain forest vegetation of 'Eua Island, Kingdom of Tonga. New Zealand Journal of Botany, 34, 65-77.

Ellstrand, N.C., Ornduff, R. \& Clegg, J.M. (1990) Genetic structure of the Australian cycad, Macrozamia (Zamiaceae). American Journal of Botany, 77, 677-681.

Fosberg, F.R. (1963) Disturbance in island ecosystems. In Pacific Basin Biogeography - A Symposium (ed. J.L. Gressit), pp. 189-191. Bishop Museum Press, Honolulu, Hawaii.

Frankel, O.H. \& Soulé, M.E. (1981) Conservation and Evolution. Cambridge University Press, Cambridge, UK.

Franklin, I.R. (1980) Evolutinary change in small populations. In Conservation Biology. An Evolutionary-Ecological Perspective (eds M.E. Soulé \& B.A. Wilcox), pp. 135-149. Sinauer Associates, Sunderland, Massachusettes, USA.

Franklin, J., Drake, D.R., Bolick, L.A., Smith, D.S. \& Motley, T.J. (1999) Rain forest composition and patterns of secondary succession in Vava'u Island Group, Tonga. Journal of Vegetation Science, 10, 51-64.

Guppy, H.B. (1906) Observations of a Naturalist in the Pacific between 1896 and 1899. Volume II: Plant Dispersal. Macmillan and Co., Ltd, London, UK.

Hamrick, J.L. \& Godt, M.J.W. (1996) Conservation genetics of endemic plant species. In Conservation Genetics - Case Histories from Nature (eds J.C. Avise \& J.L. Hamrick), pp. 281-304. Chapman \& Hall, New York, Massachusetts, USA.

Hamrick, J.L., Godt, M.J.W. \& Sherman-Broyles, S.L. (1992) Factors influencing genetic diversity in plant species. New Forests, 6, 95-124.

Hill, K.D. (1994) The Cycas rumphii complex (Cycadaceae) in New Guinea and the Western Pacific. Australian Systematic Botany, 7, 543-567.

Hill, K.D. \& Stevenson, D.W. (1998) The Cycad Pages. http:/ / plantnet.rbgsyd.gov.au/PlantNet/cycad/ (last visited: August 2001).

Hilton-Taylor, C. (compiler) (2000) 2000 IUCN Red List of Threatened Species. IUCN, Gland, Switzerland and Cambridge, UK

IUCN Species Survival Commission (1994) IUCN Red List Categories. IUCN, Gland, Switzerland.

Jones, D.L. (1993) Cycads of the World. Reed, Chastwood, NSW, Australia.

Keating, M. (1993) The Earth's Summit's Agenda for Change. A Plain Language Version of Agenda 21 and Other Rio Agreements. Centre for Our Common Future, Geneva, Switzerland.

Keppel, G. (1999) Population genetics, phylogeny, ecology, and the conservation status of Cycas seemannii A.Br. (Cycadaceae). M.Sc. thesis, University of the South Pacific, Suva, Fiji.

Keppel, G. (2001) Notes on the natural history of Cycas seemannii (Cycadaceae). South Pacific Journal of Natural Sciences, 19, 35-42.

Keppel, G., Lee, S.-W. \& Hodgskiss, P.D. (in press) Evidence for long isolation among populations of a Pacific cycad: Genetic diversity and differentiation in Cycas seemannii A.Br. (Cycadaceae). Journal of Heredity. 
Lande, R. (1988) Genetics and demography in biological conservation. Science, 241, 1455-1460.

Latham, M. (1979) The natural environment of Lakeba. In Lakeba: Environmental Change, Population Dynamics and Resource Use (ed. H.C. Brookfield), pp. 17-55.

UNESCO/UNFPA - Island Reports No. 5. Australian National University, Canberra, Australia.

Latham, M. (1983) Origin of the talasiga formation. In The Eastern Islands of Fiji (eds M. Latham \& H.C. Brookfield), pp. 129-141. UNESCO/UNFPA - General Report No. 3, Paris, France.

Laubenfels, J.D. de (1972) Gymnospermes. In Flore de la Nouvelle-Calédonie et dépendances (eds A. Aubreville \& J.F. Leroy). Muséum National D’Histoire Naturelle, Paris, France.

Ledig, F.T., Gurries, R.P. \& Bonefeld, B.A. (1983) The relation of growth to heterozygosity in pitch pine. Evolution, 37, 1227-1238

Lees, A. (1989) A Representative National Park and Reserves System for Fiji's Tropical Forests. Maruia Society Policy Reports Series No. 9, May 1989. Maruia Society, Nelson, New Zealand.

Lewis, P.O. \& Zaykin, D. (1999) Genetic Data Analysis: Computer Program for the Analysis of Allelic Data. Version 1.0 (d12). Free programme distributed by the authors over the internet from the GDA Home Page at http:/ / alleyn.eeb.uconn.edu/gda/

Lynch, M. (1996) A quantitative-genetic perspective on conservation issues. In Conservation Genetics - Case Histories from Nature (eds J.C. Avise \& J.L. Hamrick), pp. 471-501. Chapman \& Hall, New York, Massachusetts, USA.

MacArthur, R.H. \& Wilson, E.O. (1967) The Theory of Island Biogeography. Princeton University Press, Princeton, New Jersey, USA.

Mead, J.P. (1928) The Forests of the Fiji Islands. Council Papers on Fiji, 4, 47-54.

Millar, C.I. \& Westfall, R.D. (1992) Allozyme markers in forest genetic conservation. New Forests, 6, 347-371.

Mueller-Dombois, D. \& Fosberg, F.R. (1998) Vegetation of Tropical Pacific Islands. Springer Verlag, New York, USA.

Murphy, R.W., Sites Jr., J.W., Buth, D.G. \& Haufler, C.H. (1996) Proteins: Isozyme Electrophoresis. In Molecular Systematics (eds D.M. Hillis, C. Moritz \& B.K. Mabel), pp. 51-120. Sinauer Associates, Sunderland, Massachusettes, USA.

Nei, M. (1973) Analysis of gene diversity in subdivided populations. Proceedings of the National Academy of Sciences of the USA, 70, 3321-3323.

Nei, M. (1978) Estimation of average heterozygosity and genetic distance from a small number of individuals. Genetics, 89, 583-590.

Nei, M. (1987) Molecular Evolutionary Genetics. Columbian University Press, New York, USA.

Niklas, K.J. \& Norstog, K. (1984) Aerodynamics and pollen grain depositional patterns on cycad megastrobili: Implications on the reproduction of three cycad genera (Cycas, Dioon, and Zamia). Botanical Gazette, 145, 92-104.

Norstog, K.J. \& Fawcett, P.K.S. (1992) Mexican Cycads - 1991. Encephalartos, 30, 14-19.

Norstog, K.J. \& Nicholls, T.J. (1997) The Biology of the Cycads. Cornell University Press, Ithaca, New York, USA.
Ono, M. (1998) Conservation of the endemic vascular plant species of the Bonin (Ogasawara) Islands. In Evolution and Speciation of Island Plants (eds T.F. Stuessy \& M. Ono), pp. 169-180. Cambridge University Press, Cambridge, UK.

Ornduff, R. (1991) Size classes, reproductive behaviour and insect associates of Cycas media (Cycadaceae). Botanical Gazette, 152, 205-207.

Osborne, R. (1995) The 1991-1992 world cycad census and a proposed revision of the I.U.C.N threatened species status for cycads. In Proceedings of the Third International Conference of Cycad Biology (ed. P. Vorster), pp. 65-83. Cycad Society of South Africa, Stellenbosch, South Africa.

Reynolds, J., Weir, B.S. \& Cockerham, C.C. (1983) Estimation of the coancestry coefficient: basis for a short-term genetic distance. Genetics, 105, 767-779.

Riesenberg, L.H. \& Swensen, S.M. (1996) Conservation genetics of endangered island plants. In Conservation Genetics - Case Histories from Nature (eds J.C. Avise \& J.L. Hamrick), pp. 305-334. Chapman \& Hall, New York, Massachusetts, USA.

Schmid, P.M. (1975) La flore et la végétation de la partie méridonale de l'Archipel des Nouvelles Hébrides. Philosophical Transactions of the Royal Society London, Series B, 272, 329-342.

Schoen, D.J. \& Brown, A.H.D. (1991) Intraspecific variation in population gene diversity and effective population size correlates with mating systems in plants. Proceedings of the National Academy of Sciences of the USA, 88, 4494-4497.

Seemann, B. (1865-73) Flora Vitiensis: A Description of the Plants of the Viti or Fiji Islands with an Account of their History, Uses, and Properties. L. Reeve and Co., London, UK.

Singh, S.M. \& Zouros, E. (1978) Genetic variation associated with growth rate in the American oyster (Crassotrea virginica). Evolution, 32, 342-353.

Slatkin, M. (1985) Rare alleles as indicators of gene flow. Evolution, 39, 53-65.

Swofford, D.L. \& Selander, R.B. (1989) BIOSYS-1. A Computer Programme for the Analysis of Allelic Variation in Population Genetics and Biochemical Systematics. Release 1.7. Illinois Natural History Survey, Urbana, Illinois, USA.

Templeton, A.R. (1986) Coadaptation and outbreeding depression. In Conservation Biology - The Science of Scarcity and Diversity (ed. M.E. Soulé), pp. 105-116. Sinauer Associates Inc., Sunderland, Massachusetts, USA.

Thaman, R.R. (1992) Batiri kei Baravi: the ethnobotany of Pacific island coastal plants. Atoll Research Bulletin, 361, $1-62$.

Walter, K.S. \& Gillet, H.J. (eds) (1998) 1997 IUCN Red List of Threatened Plants. IUCN - The World Conservation Union, Gland, Switzerland.

Walters, T.W. \& Decker-Walters, D.S. (1991) Patterns of allozyme diversity in the West Indies cycad Zamia pumila (Zamiaceae). American Journal of Botany, 78, 436-445.

Weir, B.S. \& Cockerham, C.C. (1984) Estimating F-statistics for the analysis of population structure. Evolution, 36, 1358-1370.

Whitelock, L.M. (1995) Cycad conservation in the past and the need for improvements in the future. In Proceedings of the Third International Conference of Cycad Biology (ed. P. Vorster), pp. 1-8. Cycad Society of South Africa, Stellenbosch, South Africa. 
Wilson, G.W. (1993) Initial observations of the reproductive behaviour and an insect pollination agent of Bowenia serrulata (W. Bull) Chamberlain. Encephalartos, 36, 13-18.

Wright, S. (1951) The genetical structure of populations. Annals of Eugenics, 15, 323-354.

Yang, S.-L. \& Meerow, A.W. (1996) The Cycas pectinata (Cycadaceae) complex: Genetic structure and gene flow. International Journal of Plant Science, 157, 468-483.

Yeh, F.C., Yang, R.-C., Boyle, T.J.B., Ye, Z.-H. \& Mao, J.X. (1997) POPGENE, the User-friendly Shareware for Population Genetic Analysis. Molecular Biology and Biotechnology Centre, University of Alberta, Alberta, Canada.

\section{Biographical sketch}

Gunnar Keppel is an Assistant Lecturer in Plant Biology at the University of the South Pacific in Suva, Fiji. His interests are in the ecology, evolution, population genetics and conservation of plants, especially gymnosperms, and in the identification of flowering plants in the absence of flowers and fruits. He is also participating in the Pacific Asia Biodiversity Transect (PABITRA). 